\title{
TRANSFORMATION OF LABOR LEGISLATION IN THE DIGITAL ECONOMY
}

\author{
Mykola Inshyn* \\ Tetiana Vakhonieva** \\ Andrii Korotkikh ${ }^{* * *}$ \\ Anatolii Denysenko**** \\ Khrystyna Dzhura ${ }^{* * * * * *}$
}

\begin{abstract}
The purpose of this study, which is based on the method of political and legal analysis, is to identify and assess the modern challenges faced by legal systems of different states in the field of adaptation of labor legislation to new types of social and legal relations arising under the influence of the digital economy. This study allows asserting that today's adaptation of labor legislation of different countries in the conditions of the digital economy is at the initial stages and the existing legal mechanisms are not entirely adapted to many new types of legal relations. The evolution of this legislation today is slowed down by the lack of a sufficient conceptual apparatus, a clearly defined sphere of legislative regulation, which in turn is also due to dynamic changes in the field of digital technologies. This study can be used to improve legal regulation in the field of labor law.
\end{abstract}

KEYWORDS: digital platforms, employer, labor relations, protection of labor rights, reform.

\footnotetext{
Mykola Inshyn, Taras Shevchenko National University of Kyiv, Kyiv, Ukraine; nikolainshin@univ.kiev.ua.

** Tetiana Vakhonieva, Taras Shevchenko National University of Kyiv, Kyiv, Ukraine; tatiana_vah@univ.kiev.ua.

**** Andrii Korotkikh, InterRegional Academy of Personnel Management, Kyiv, Ukraine; senior.corotcih@iapm.edu.ua.

***** Anatolii Denysenko, InterRegional Academy of Personnel Management, Kyiv, Ukraine; denysenkoa@iapm.edu.ua.

***** Khrystyna Dzhura, Taras Shevchenko National University of Kyiv, Kyiv, Ukraine; kdzura. advokat@univ.kiev.ua.
} 


\section{INTRODUCTION}

The developing digital economy and associated economic terms usually do not have generally accepted definitions. In the relevant scientific literature and analytical materials of various organizations, there may be many interpretations of the same term in this area. ${ }^{1}$ This is due to the novelty and lack of sufficient understanding or clarity regarding this phenomenon. This is also closely related to the high rate of technological progress, while the time required to agree on unified standard definitions is often not comparable to the rate of technological change. In this context, a balance needs to be found between abandoning so-called "constraining" definitions that can block progress and achieving a common understanding of the relevant concepts. In a rapidly changing world, all spheres of legal relations of which invariably need legal regulation, it is important to have flexible definitions. On the other hand, to correctly analyze the problems and develop the mentioned legal regulation, it is necessary to come to a common opinion about the meaning of the terminology used. This is directly related to the issues of adaptation of labor legal relations and legislative regulation in the field of labor law to the digital economy model. ${ }^{2}$ The digital economy as a new level of development of the classical economy is a global trend that sets a new development paradigm for all states of the world. ${ }^{3}$

Today the labor market in the world is undergoing fundamental and comprehensive changes. Numerous occupations such as production line workers, proofreaders, statisticians, etc. are at risk of extinction as they can be replaced by robotics or software. The traditional professions can be replaced by fundamentally new types of labor activity, which implies flexible labor functions, specialists' learning ability, and the universality of skills that can easily adapt to new requirements and tasks of an enterprise. In this regard, there is no doubt that the movement towards the digital economy will have affect related to the existing economic paradigms. It will also be necessary to form a legislative framework that can become the basis for regulating the sphere of fundamentally new types of social relations that appear with the development of digital society.

Modern studies concerning the transformation of the sphere of labor legislation and legal relations in the context of adaptation to the digital economy are devoted to such issues as:

\footnotetext{
1 UNCTAD: UNCTAD “Digital Economy Report 2019”, [https://unctad.org/system/files/ official-document/der2019_en.pdf], accessed on 07/01/2021.

2 UNCTAD: UNCTAD “Digital Economy Report 2019”, [https://unctad.org/system/files/ official-document/der2019_en.pdf], accessed on 07/01/2021.

3 Savina, T.N.: Digital economy as a new development paradigm: challenges, opportunities and prospects, Finance and Credit, 24(3.771) 2018, p. 579-590.
} 
- the problems of labor relations in the digital economy; ${ }^{4}$

- the importance of the digital economy for labor, ${ }^{5}$

- the concept of digital supervision of compliance with labor legislation; ${ }^{6}$

- digital economy, information society and social challenges of the near future; ${ }^{7}$

- the role of the digital economy in the development of the human capital market; 8

- transformation of the labor market in the digital economy; ${ }^{9}$

- law and the emergence of new social relations created by the digital economy. ${ }^{10}$

The relevance of this study is determined by new, emerging types of social relations that require legislative regulation. Thus, the study aims to analyze the modern challenges faced by legal systems of different states in the field of adapting labor legislation to new types of social and legal relations arising under the influence of the gradual formation of the digital economy.

\section{METHODS}

The study is based on an analysis of the legislative acts of foreign states, in particular:

- Lithuania (Labor Code of the Republic of Lithuania);

- Poland (Labor Code of Poland);

4 Artecona, R.; Chau, T.: Labour issues in the digital economy, Eclac Office, Washington, 2017.

5 Drahokoupil, J.; Jepsen, M. The digital economy and its implications for labour. 1. The platform economy, Transfer, 23(2) 2017, p. 03-119.

6 Tereliansky, P.V. et al.: The Concept of Digital Supervision of Compliance with Labor Legislation, in: "Smart Technologies" for Society, State and Economy. ISC 2020. Lecture Notes in Networks and Systems, vol 155, Springer, Cham, 2021, p. 11-19.

7 Malakhova, E. et al:: Digital economy, information society and social challenges in the near future, European Research Studies, 21(1) 2018, p. 576.

8 Abdurakhmanova, G. et al.: The Role of the Digital Economy in the Development of the Human Capital Market, International Journal of Psychosocial Rehabilitation, 24(7) 2020, p. 8043-8051.

9 Goloventchik, G.G.: Transformation of the Labor Market in the Digital Economy, Digital Transformation, 4(5) 2019, p. 27-43.

10 Waas, B. et al.: Digital economy and the law: introduction to this Special Issue, Work Organisation, Labour and Globalisation, 12(2) 2018, p. 7-11. 
- Russia (Labor Code of the Russian Federation, Federal Law No. 439-FZ of December 16, 2019, "On Amendments to the Labor Code of the Russian Federation in terms of generating information on labor activity in electronic form");

- Kazakhstan (Labor Code of the Republic of Kazakhstan);

- France (Law of the French Republic of 08 Aug 2016 On labor, modernization of social dialogue and career support);

- Ukraine (Order of the Cabinet of Ministers of Ukraine dated January 17, 2018, No. 67-r "On Approval of the Concept for the Development of the Digital Economy and Society of Ukraine for 2018-2020 and Approval of the Action Plan for its Implementation").

The study also analyzed the UNCTAD analytical document "DIGITAL ECONOMY REPORT 2019”.

Using the method of political and legal analysis, the work examines:

- the role and significance of legislative regulation of labor relations in the context of the digital economy;

- modern practices of legislative regulation;

- labor legislation reforms of different states in adapting to new types of social legal relations;

- relevant recommendations regarding possible measures to overcome legal gaps.

\section{RESULTS}

The digital economy is a term that reflects the impact of digital technology on production and consumption patterns, including how goods and services are sold, bought, and paid for. The term originated in the 1990s when the focus was on the impact of the Internet on the economy. Its appearance was due to the need to describe the processes associated with the emergence of new types of firms focused on digital technologies, and the production of new technologies. ${ }^{11}$

Today, the term encompasses a vast array of technologies and electronic applications, including artificial intelligence, the Internet of Things, augmented and virtual reality, cloud computing, blockchain, robotics, and autonomous vehicles. It is now recognized that the digital economy includes all parts of

${ }_{11}$ Drahokoupil, J.; Jepsen, M. The digital economy and its implications for labour. 1. The platform economy, Transfer, 23(2) 2017, p. 03-119. 
the economy that embrace technological change, leading to the transformation of markets, business models, and day-to-day operations. Thus, the term covers everything from traditional technologies, media, and telecommunications to new digital sectors. These include e-commerce, digital banking, and even "traditional" sectors such as agriculture, mining, or manufacturing, which are influenced by the use of new technologies.

The entry of the concept of "digital economy" into scientific use has become an indisputable fact. There is no doubt that the digital economy will soon turn into a conventional economy as the spread and use of digital technologies in every part of the world increases. ${ }^{12}$

Due to the development of information and communication technologies, the digital economy differs from the existing model of the real economy by:

- the direct interaction of a producer and a consumer;

- the personification of the results of labor;

- the availability of goods and services via the Internet;

- the entry into the use of electronic money;

- the spread of new, previously non-existent specialties on the labor market.

The latest trends in the development of social and labor relations are, among other things, distance employment, work in the "cloud", crowdsourcing, freelancing, and flexible forms of employment. ${ }^{13}$

The main reasons for the transformation of social and labor relations in the digital economy are:

- strengthening of the social component in labor relations;

- development of non-standard forms of labor relations;

- the blurring of the boundaries between work and leisure;

- differences in value preferences of generations;

- orientation of education towards the computerized labor market.

\footnotetext{
12 de Freitas, W.: The digital economy is becoming ordinary. Best we understand it, The Conversation, 2020, [https://theconversation.com/the-digital-economy-is-becoming-ordinary-bestwe-understand-it-130398], accessed on 07/01/2021.

13 Nazarova, G.V.: Transformation of social and labor relations in the digital economy, Bulletin of Voronezh State University. Series: Economics and Management, 3(1) 2019, p. 91-95.
} 
State regulation and the legislative framework should move towards reducing the requirements for paper documents. ${ }^{14}$

It should be noted that many modern countries do not have appropriate legislative instruments in the field of digital economic relations. In particular, many underdeveloped states do not have any legal regulations regarding online financial transactions. A useful starting point for many countries is, first and foremost, a regulatory gap analysis that will provide a framework for a holistic approach to formulating laws and other legislation necessary for the free use of e-commerce and the digital economy. Then, it will be necessary to adopt basic legislation on e-commerce or update relevant laws and other legislation following international best practices. Areas of particular relevance include legislation related to electronic transactions, consumer protection, data protection, intellectual property, and cybercrime. The adoption of laws and regulations should be complemented by their effective law enforcement, as well as a corresponding strengthening of legislative, law enforcement capacity, and judicial practice. ${ }^{15}$

Thus, in the legislation of many countries, norms are regulating flexible labor relations and their forms, which have been enshrined both in individual laws and in labor codes, for example:

- Law of the Hellenic Republic No. 2639/1998 "Regulation of labor relations, the composition of labor inspection and other provisions";

- Labor Code of the Republic of Kazakhstan;

- Labor Code of the Republic of Lithuania;

- Labor Code of Poland, etc.

In particular, the Polish Labor Code deals with the conditions for performing regular work outside a company (in the form of teleservices) using electronic means of communication. A remote worker is considered an employee who does work outside a company and communicates the results of his/her work to an employer via electronic means. At the same time, the introduction of a policy of flexibility of forms and regimes should not reduce the protective function of labor law, which is seen in the protection of the rights and interests of subjects of labor law and is a priority concerning the economic one. ${ }^{16}$ French

14 Nazarova, G.V.: Transformation of social and labor relations in the digital economy, Bulletin of Voronezh State University. Series: Economics and Management, 3(1) 2019, p. 91-95.

15 Party of European Socialists: Workers' rights and social progress in the digital economy, Party of European Socialists, 2017, [http://www.pervencheberes.fr/wp-content/uploads/2017/09/digital-economy-brochure-web-version-002.pdf], accessed on 07/01/2021.

16 Arsentieva, O.S.; Kotova, L.V.: On the Relationship between Flexibility and State Regulation of the Labor Market in the Era of Digital Economy, in: MATERIALS of the Internation- 
legislation on the protection of labor rights in the digital economy is, among other things, represented by the Law of 08 Aug 2016 on labor, modernization of social dialogue, and career support (LOI n 2016-1088 du 8 août 2016 relative au travail, à la modernisation du dialogue social et à la sécurisation des parcours professionnels). ${ }^{17}$ This Law provides for an employee's right to be disconnected from digital devices (telephone, email) in order to respect his/her rest time, as well as private and family life..$^{18}$

The 2019 Global Commission on the Future of Work report, among other things, noted that technological advances (including artificial intelligence, automation, and robotics) will create new jobs, but those who lose their jobs during this transition period may be the least prepared to take advantage of new opportunities. Thus, the skills in demand today will not match the jobs of tomorrow, and newly acquired skills can quickly become obsolete. ${ }^{19}$

Considering the CIS countries and the EAEU in the context of adapting their labor legislation to the digital economy, it should be noted that for these countries, global digital transformation creates a wide range of challenges both for their economies at the macroeconomic level and at the level of their business entities and citizens. Remaining within the framework of traditional processes, relations, and connections without the development of the digital economy and joint implementation of projects within the digital agenda, member states can deprive themselves of new opportunities. At the same time, it should be noted that in recent years, these states have been characterized by the release of significant labor resources and the emergence of imbalances in all sectors of the economies of the member states, the flow of labor resources into the digital economies of third countries and the digital ecosystems of global digital platforms. At the same time, there is a need for a more reliable institutional form for the protection of personal data with a balance of protection in the context of cross-border exchange. In the described context, in the coming years, it will not come as a surprise if these countries face the depreciation of traditional

al scientific-practical conference of scientists, lawyers and graduate students "Legal means of ensuring and protecting human rights: domestic and foreign experience", Severodonetsk, Ukraine, 2019, p. 32-36.

17 Legifrance: LOI $n^{\circ}$ 2016-1088 du 8 août 2016 relative au travail, à la modernisation du dialogue social et à la sécurisation des parcours professionnels (1), Legifrance, 2016, [https://www. legifrance.gouv.fr/loda/id/LEGITEXT000033000929/2019-03-09/], accessed on 07/01/2021.

18 Tomashevsky, K.L.: Digitalization and its impact on the labor market and labor relations (theoretical and comparative legal aspects), Bulletin of St. Petersburg University. Right, 11(2) 2020, p. 398-413.

19 ILO: Global Commission on the Future of Work, ILO, 2019, [https://www.ilo.org/infostories/en-GB/Campaigns/future-work/global-commission\#intro], accessed on 07/01/2021. 
assets at the state level and the level of business entities of the member states, without adapting to the digital transformation of the economy. ${ }^{20}$

Under the conditions of the Russian legal system, the emergence of such types of employment as remote work has become the reason for the appearance in the Labor Code of the Russian Federation of Chapter 49.1 "Features of the regulation of labor of remote workers". According to article 312.2 of the Labor Code of the Russian Federation, an employment contract on teleworking and agreements on changing the terms of an employment contract on teleworking determined by the parties can be concluded through the exchange of electronic documents. However, when an employment contract for teleworking is concluded through the exchange of electronic documents, then an employer, no later than three calendar days from the date of conclusion of this employment contract, is obliged to send the remote worker by mail a copy of this employment contract on paper.

To date, the difficulties in formalizing labor relations have not been finally settled. This is partly due to certain costs for both employees and employers. Sending documents to millions of employees costs employers a large amount - from 5 to 7 billion rubles a year, and the purchase of qualified electronic signatures costs employees from 3 to 5 billion rubles a year, which in most cases leads to the refusal to conclude an employment contract and, as a result, to informal employment.

In addition, in modern realities, the question arises about the wider application of the digital economy associated with the legal regulation of labor and relations directly related to them in the legalization of electronic document flow. One of the most promising areas of activity is the introduction of electronic employment record books. ${ }^{21}$ In the Russian legal environment, this issue has long caused controversy, however, in January 2020, Federal Law No. 439-FZ of December 16, 2019, was adopted "On Amendments to the Labor Code of the Russian Federation in terms of generating information about labor activity in electronic form" (The Law on Electronic Employment Record Books). This Law allows Russians to keep this document in digital format, but also provides for the preservation of a paper version if they wish. According to the

\footnotetext{
20 Tomashevsky, K.L.: Digitalization and its impact on the labor market and labor relations (theoretical and comparative legal aspects), Bulletin of St. Petersburg University. Right, 11(2) 2020, p. 398-413.

21 Rogaleva, I.; Rogaleva, G.: Features of registration of labor relations in the digital economy, Bulletin of the Russian Economic University. G.V. Plekhanov, 4(100) 2018, p. 184-189.
} 
law, employees have the right to request from their employer data on their work activities both in hard copy and in electronic format. ${ }^{22}$

A novelty in the legislation of the Russian Federation (from July 1, 2017) was the introduction of amendments to clause 3.2 of Article 59 of the Federal Law of November 21, 2011, No. 323-FZ "On the basics of protecting the health of citizens in the Russian Federation". Under this act, a sick leave document is envisaged to be issued in the form of a paper document or (with the patient's written consent) in the form of an electronic document signed with the use of an electronic signature by a medical professional and a medical organization. In order to implement this innovation, a medical institution and an employer must participate in the information interaction system, and for an insured person (employee) - to express his/her consent in writing to the formation of a sick leave document in e-form. ${ }^{23}$

In August 2019, in his message to the Verkhovna Rada of Ukraine, President of Ukraine V. Zelensky named building a digital state in a smartphone among the strategic principles of the country's development. The President's initiative was confirmed by the order of the Cabinet of Ministers of Ukraine dated January 17, 2018, No. 67-r. This order approved the Concept for the Development of the Digital Economy and Society of Ukraine for 2018-2020 (hereinafter - the Concept) and approved an action plan for its implementation, the main goal of which is to create the necessary conditions for the development of the digital economy in Ukraine.

However, it should be noted that the current legislation of Ukraine governing atypical (legal relations in the digital field) relations is fragmented. The Labor Code of Ukraine lacks separate sections regulating outsourcing, fixed-term relationships, and remote work (present in the labor codes of some previously mentioned foreign countries). At the same time, the draft Labor Code of Ukraine contains several articles that concern the introduction of flexibility in labor relations, in particular, a flexible form of employment - work from home. Article 147 of the draft contains provisions on flexible working hours. At the same time, Art. 148 of the draft states that the heads of legal entities and separate divisions, workers working at home, remotely, and other categories of workers plan their working hours independently unless otherwise specified in the employment contract. Legislation may provide for the right of employees to

22 The State Duma: Federal Law of December 16, 2019 N 439-FZ "On Amendments to the Labor Code of the Russian Federation in terms of generating information about labor activity in electronic form”, [https://rg.ru/2019/12/19/trud-dok.html], accessed on 07/01/2021.

23 Rogaleva, I.; Rogaleva, G.: Features of registration of labor relations in the digital econo$m y$, Bulletin of the Russian Economic University. G.V. Plekhanov, 4(100) 2018, p. 184-189. 
independently plan their working hours, subject to compliance with the deadlines for the performance of work (scientific, scientific-pedagogical workers, and others). Such a category of workers as "workers working remotely" has emerged, although Article 42 of the draft does not contain such type of work as remote work. ${ }^{24}$

In September 2020, the Verkhovna Rada of Ukraine in the first reading adopted as a basis the draft law No. 3623 on amendments to some legislative acts of Ukraine regarding the accounting of the employee's labor activity in electronic form. They are invited to transfer physical employment record books into electronic form, as well as introduce the possibility of automatic assignment of pensions. The draft provides for the complete transfer of employment record books into electronic form until 2025. It is assumed that they will be in the register of insured persons of the State Register of Compulsory State Social Insurance. The Pension Fund is responsible for the safety of the registers. For five years, the Pension Fund will transfer information about the labor activity of citizens to the State Register. During the transition period, both paper and electronic forms of employment record books will be used. The calculation of pensions is supposed to be made automatic. At the same time, a citizen will be able to choose the day when the funds will be received. Due to the availability of data on work experience in the register, the need for its official confirmation will disappear. ${ }^{25}$

\section{DISCUSSION}

On a global scale, among the main problems that can become an obstacle to the introduction of effective "digital" regulation of social and labor relations are the following. Firstly, it is the existence of unequal conditions in the availability and use of the Internet in large cities and rural areas, in the mentality of young people and the elderly, in the popularity of various software products (computer games and government websites). Secondly, the legislation of all countries of the world in the field of socio-economic relations lags behind the rapid development of the digital economy. Thirdly, the information economy

\footnotetext{
24 Arsentieva, O.S.; Kotova, L.V.: On the Relationship between Flexibility and State Regulation of the Labor Market in the Era of Digital Economy, in: MATERIALS of the International scientific-practical conference of scientists, lawyers and graduate students "Legal means of ensuring and protecting human rights: domestic and foreign experience", Severodonetsk, Ukraine, 2019, p. 32-36.

25 Gritsyk, T.: Rada adopted the law on electronic work books in the first reading, AIN, 2020, [https://ain.ua/2020/09/03/rada-prinyala-zakon-ob-elektronnyx-trudovyx-knizhkax-v-pervom-chtenii/], accessed on 07/01/2021.
} 
carries information threats and risks of losing important information in socially important databases and communications. Among the main threats are cyberattacks on social and pension funds, disclosure of clients' information in social databases, theft of social funds, danger to client accounts of banks and government agencies. ${ }^{26}$

Moreover, it is no exaggeration to say that there is an urgent need for political or supranational debate about preparing workers for the new reality that the digital economy is shaping. The following problems are concerned with adaptation:

- misclassification of workers in digital work platforms;

- the lack of social security systems for workers in the digital economy, who, in fact, are not considered employees;

- isolation nature of such work. ${ }^{27}$

In the conditions of CIS countries' legal systems, based on the example of Russia, Ukraine, it is quite important to consider the issue of the digital economy's wider application associated with the legal regulation of labor relations in the legalization of electronic documents circulation. In Russia, despite numerous doubts, electronic employment record books found their legislative consolidation. This example once again testifies to the importance of political will in matters of legal transformation in the digital economy. ${ }^{28}$

Digital technologies can have a big impact on the protection of citizens' labor rights through digital surveillance of labor compliance. This can be facilitated by automatic remote interaction of information systems used by employers for personnel records, with a specialized software package for monitoring and preventing offenses and means of remote collection and analytical processing of data on employers' activities. The use of these tools will allow one to more accurately determine the risks of harm in the field of work and respond more quickly to increasing risks for regulatory authorities. ${ }^{29}$

Regarding clear examples of the positive role of labor legislation transformation in the digital economy in terms of protecting the labor rights of an employ-

\footnotetext{
26 Nazarova, G.V.: Transformation of social and labor relations in the digital economy, Bulletin of Voronezh State University. Series: Economics and Management, 3(1) 2019, p. 91-95.

27 Artecona, R.; Chau, T.: Labour issues in the digital economy, Eclac Office, Washington, 2017.

28 Rogaleva, I.; Rogaleva, G.: Features of registration of labor relations in the digital economy, Bulletin of the Russian Economic University. G.V. Plekhanov, 4(100) 2018, p. 184-189.

29 Popkova, E.G.; Sergi, B.S.: “Smart Technologies” for Society, State and Economy. Lecture Notes in Networks and Systems. Springer, Cham, 2021.
} 
ee, the following can be noted. In the case of paper employment record books, situations often arose when an employer did not give them to employees (for blackmail purposes), did not mark certain positions in a document, and made mistakes when entering data. As a result, an employee became a victim who was in no way insured against such situations. The introduction of electronic employment record books is aimed at solving these problems. In addition, an employee has access to information about work activity in his/her personal account on a unified state web resource. Thus, an employee can control the actions of an employer: whether the latter timely transmit information about work activities in a personal web account. An employee will not have to wait to get back an employment record book upon dismissal: it will be possible to request information in a personal account on the website of authorized service and transfer it to a future employer. In addition, an employer also benefits from the transition to electronic employment record books, since he/she is relieved of responsibility for storing paper employment record books, and through the use of the web service, human errors are excluded when transferring information about work activities. ${ }^{30}$

However, considering the issue of abolishing paper employment record books in the conditions of the Ukrainian legal system, the disadvantages of digital transformation should also be noted. Thus, the trade union of nuclear industry workers expressed the opinion that existing legislative initiatives not only carry risks of significant violations of the labor and social rights of workers in the industry but can also lead to an infringement of citizens' rights, primarily in the field of social insurance. Basically, this opinion is based on the fact that today employment record books are necessary when calculating the length of service for the appointment of pensions as well as determining unemployment benefits. However, in the register of compulsory state insurance, which has been kept since 2004, there are no complete data on jobs with harmful and difficult working conditions.

Based on this statement, it is worth noting that the implementation of the reform should initially be based on pre-created integrated national registers containing summary information on workers, unemployed, and pensioners and taking into account all sorts of additional circumstances that can affect the calculation of seniority.

At the same time, it is still unclear how the reason for termination of labor relations will be recorded in the register since today the phrase "by their own

30 Sarvarova, Y.: Electronic work books: why it is good and what will happen next, ECM-Journal, 2020, [https://ecm-journal.ru/docs/Ehlektronnye-trudovye-knizhki-pochemu-ehto-khorosho-i-chto-budet-dalshe.aspx], accessed on 07/01/2021. 
free will" or "by agreement of the parties" is put in the employment record book. At the same time, if the fact confirming that a person does not work at the enterprise is simply entered in the register, then the question arises as to what grounds it is possible to appeal against the employer's decision in court. ${ }^{31}$

In addition, the very intention of the authorities to enter a large amount of data into the electronic database, including digital photography, data on travel abroad, etc., raises questions about whether government agencies are able to ensure the security of these data. In addition, presumably, this circumstance is capable of allowing the authorities to totally control all aspects of citizens' lives. ${ }^{32}$

In the context of innovative technologies and new business models, it is important to prevent new types of offenses, generated by new types of legal relations, in particular in the field of social protection of employees. Digital economy, like market, traditional, or any other economy, involves payment of taxes and social security contributions, compliance with social protection legislation, and ensuring consumer protection. At the same time, high potential for transparency in the digital economy implies ensuring good traceability of offenses.

For the digital economy to have the maximum positive effect in the social sphere, new forms of work must include the integration of costs of social protection. ${ }^{33}$

Initially, digital platforms assumed traceability of exchanges as a means of transactions. From this perspective, technological tools such as geolocation and reporting documents fully (to an acceptable extent) contribute to the openness of processes. The use of existing technological solutions that can help integrate social security costs into new forms of work would be an additional tool for the protection of labor rights and the openness of legal relations. In fact, the technologies offered by the platforms can make employment regulation more effective as it allows for efficient monitoring of microtransactions as well as their inclusion in insurance systems. Platform-assisted monitoring can also help in ensuring compliance with health and safety regulations. ${ }^{34}$

\footnotetext{
31 Konovalova, K.: Abolition of employment records: how Ukrainians will be able to prove their work experience, Buhgalter, 2019, [https://buhgalter.com.ua/news/kadrova-sprava/skasuvannya-trudovih-knizhok-yak-ukrayintsi-zmozhut-dovesti-sviy/], accessed on 07/01/2021.

32 Konovalova, K.: Cancellation of work books: how Ukrainians can prove their work experience, HR Liga, 2019, [https://hrliga.com/index.php?module=news\&op=view\&id=21032], accessed on 07/01/2021.

33 Quarta, A.: Narratives of the Digital Economy: How Platforms Are Challenging Consumer Law and Hierarchical Organization, Global Jurist, 20(2) 2020, p. 20200026.

34 Demailly, D.; Novel, A.S.: The sharing economy: make it sustainable, Studies, 3(14) 2014, p. 14-30; Drahokoupil, J.; Fabo, B.: The Sharing Economy That Is Not: Shaping Employment
} 
To ensure the maximum positive effect on labor relations, the mechanisms of web platforms can provide for solutions such as deduction of a tax corresponding to a social contribution from each transaction, including social insurance contributions, which are included in the price of the sold service. This can only open social security entitlements to an employee after a fixed threshold is reached. At the same time, the existence of a legal tax "deductible" is also allowed below a certain level of working hours. ${ }^{35}$

Such web platforms can provide for co-financing by a client of social contributions for crowd workers (a collective form of labor organization) and individual self-employed contractors, similar to the traditional employer-employee relationship. The platform could initially withhold taxes and transfer them to government agencies. The system can be extended to all companies that massively outsource work to self-employed people.

However, to mitigate the impact of robotics and artificial intelligence on the labor market, taxes on the work performed by a robot or fees for using and maintaining a robot should be envisaged. In practice, this would balance (rebalance) the taxation of labor and the taxation of capital and could help finance social protection and retraining of workers whose jobs have disappeared as a result of automation. ${ }^{36}$

In addition, as it should happen in traditional economic systems (models), the transformation of labor legislation in the digital economy can be closely related, or even serve as a tool to continue the struggle for fair taxation. Web platforms are often not geographically bound and declare their profits where tax rates are lower. To fund social protection and prevent dumping, it is important to ensure that multinational companies pay their fair share of national taxes and fees wherever they operate. Likewise, it must be possible to ensure efficiency and enforcement of rights in situations where workers and employers are located in different countries. This can be achieved by applying EU norms and internationally agreed on decisions. Since this issue today and in the future has a supranational character to one degree or another, international political efforts should be set as the highest priority at the supranational (international) level. Existing agreements between platforms and local authorities

In Platform Capitalism, Social Europe, 2016, [https://www.socialeurope.eu/sharing-economy-not-shaping-employment-platform-capitalism], accessed on 07/01/2021.

35 Gorriz, C.: EU Company Law: Past, Present and ... Future? Global Jurist, 19(1) 2019, p. 20170029.

36 European Parliament: European Parliament resolution of 16 February 2017 with recommendations to the Commission on Civil Law Rules on Robotics (2015/2103(INL)), [https:// www.europarl.europa.eu/doceo/document/TA-8-2017-0051_EN.html?redirect], accessed on 07/01/2021. 
might be the most illustrative examples for business. At the same time, the development of legislative regulation of new types of labor relations generated by the development of the digital economy should be carried out against the background of continuing the fight against international tax evasion and tax competition, as well as increasing corporate social responsibility. ${ }^{37}$

\section{CONCLUSIONS}

It can be argued that today the adaptation of labor legislation of different countries in the context of the digital economy is at the initial stage and many countries rely on existing legal mechanisms to regulate emerging legal relations. Today there is a lack of a sufficient conceptual apparatus (the term "digital economy" exists so far only in a theoretical plane) and the limits of the legislative sphere. In the future, digital technologies can have a great impact on the protection of citizens' labor rights through mechanisms such as digital supervision of compliance with labor laws, deduction of direct contributions to social insurance funds from each transaction made, etc.

For Ukraine today, one of the "stumbling blocks" in the adaptation of labor legislation to the digital economy is the issue of legalizing electronic document management in personnel affairs. Although, in a holistic context, this is rather a particular example characterizing the general state of affairs in the field of labor legislation reform, emphasizing the fact that the process of adapting legislation to the requirements of the digital economy is moving slowly. However, it should also be noted that, first of all, employers must be willing and ready to use electronic personnel document management. The role of state structures in this process is to ensure the connection of electronic personnel document management with pension and social structures. This will reduce employer's and state's costs for ensuring an effective system of regulation of social and labor relations. For the introduction of electronic personnel document management, it is necessary to prepare the legal environment, to take into account new influences in the new Labor Code.

Given the fact that in many countries the legislation in the field of new types of labor relations associated with the digital economy is at the stage of formation, further research in this area should be aimed directly at studying the effectiveness of the adopted legislative mechanisms.

37 Party of European Socialists: Workers' rights and social progress in the digital economy, Party of European Socialists, 2017, [http://www.pervencheberes.fr/wp-content/uploads/2017/09/digital-economy-brochure-web-version-002.pdf], accessed on 07/01/2021. 


\section{LITERATURE}

1. Abdurakhmanova, G. et al.: The Role of the Digital Economy in the Development of the Human Capital Market, International Journal of Psychosocial Rehabilitation, 24(7) 2020, p. 8043-8051.

2. Arsentieva, O.S.; Kotova, L.V.: On the Relationship between Flexibility and State Regulation of the Labor Market in the Era of Digital Economy, in: MATERIALS of the International scientific-practical conference of scientists, lawyers and graduate students "Legal means of ensuring and protecting human rights: domestic and foreign experience", Severodonetsk, Ukraine, 2019, p. 32-36.

3. Artecona, R.; Chau, T.: Labour issues in the digital economy, Eclac Office, Washington, 2017.

4. de Freitas, W.: The digital economy is becoming ordinary. Best we understand it, The Conversation, 2020, [https://theconversation.com/the-digital-economy-is-becoming-ordinary-best-we-understand-it-130398], accessed on 07/01/2021.

5. Demailly, D.; Novel, A.S.: The sharing economy: make it sustainable, Studies, 3(14) 2014, p. 14-30.

6. Drahokoupil, J.; Fabo, B.: The Sharing Economy That Is Not: Shaping Employment In Platform Capitalism, Social Europe, 2016, [https://www.socialeurope. eu/sharing-economy-not-shaping-employment-platform-capitalism], accessed on 07/01/2021.

- DOI: https://doi.org/10.1177/1024258917701380

7. Drahokoupil, J.; Jepsen, M. The digital economy and its implications for labour. 1. The platform economy, Transfer, 23(2) 2017, p. 03-119.

8. European Parliament: European Parliament resolution of 16 February 2017 with recommendations to the Commission on Civil Law Rules on Robotics (2015/2103(INL)), [https://www.europarl.europa.eu/doceo/document/TA-8-20170051_EN.html?redirect], accessed on 07/01/2021.

9. Goloventchik, G.G.: Transformation of the Labor Market in the Digital Economy, Digital Transformation, 4(5) 2019, p. 27-43.

10. Gorriz, C.: EU Company Law: Past, Present and ... Future? Global Jurist, 19(1) 2019, p. 20170029.

- DOI: https://doi.org/10.1515/gj-2017-0029

11. Gritsyk, T.: Rada adopted the law on electronic work books in the first reading, AIN, 2020, [https://ain.ua/2020/09/03/rada-prinyala-zakon-ob-elektronnyx-trudovyx-knizhkax-v-pervom-chtenii/], accessed on 07/01/2021.

12. ILO: Global Commission on the Future of Work, ILO, 2019, [https://www.ilo.org/ infostories/en-GB/Campaigns/future-work/global-commission\#intro], accessed on $07 / 01 / 2021$. 
13. Konovalova, K.: Abolition of employment records: how Ukrainians will be able to prove their work experience, Buhgalter, 2019, [https://buhgalter.com.ua/news/ kadrova-sprava/skasuvannya-trudovih-knizhok-yak-ukrayintsi-zmozhut-dovesti-sviy/], accessed on 07/01/2021.

14. Konovalova, K.: Cancellation of work books: how Ukrainians can prove their work experience, HR Liga, 2019, [https://hrliga.com/index.php?module $=$ news\&op $=$ view\&id=21032], accessed on 07/01/2021.

15. Legifrance: LOI n 2016-1088 du 8 août 2016 relative au travail, à la modernisation du dialogue social et à la sécurisation des parcours professionnels (1), Legifrance, 2016, [https://www.legifrance.gouv.fr/loda/id/LEGITEXT000033 000929/2019-03-09/], accessed on 07/01/2021.

16. Malakhova, E. et al.: Digital economy, information society and social challenges in the near future, European Research Studies, 21(1) 2018, p. 576.

17. Nazarova, G.V.: Transformation of social and labor relations in the digital economy, Bulletin of Voronezh State University. Series: Economics and Management, 3(1) 2019, p. 91-95.

18. Party of European Socialists: Workers' rights and social progress in the digital economy, Party of European Socialists, 2017, [http://www.pervencheberes.fr/ wp-content/uploads/2017/09/digital-economy-brochure-web-version-002.pdf], accessed on $07 / 01 / 2021$.

19. Popkova, E.G.; Sergi, B.S.: "Smart Technologies" for Society, State and Economy. Lecture Notes in Networks and Systems. Springer, Cham, 2021.

- DOI: https://doi.org/10.1007/978-3-030-59126-7

20. Quarta, A.: Narratives of the Digital Economy: How Platforms Are Challenging Consumer Law and Hierarchical Organization, Global Jurist, 20(2) 2020, p. 20200026.

- DOI: https://doi.org/10.1515/gj-2020-0026

21. Rogaleva, I.; Rogaleva, G.: Features of registration of labor relations in the digital economy, Bulletin of the Russian Economic University. G.V. Plekhanov, 4(100) 2018, p. 184-189.

- DOI: https://doi.org/10.21686/2413-2829-2018-4-184-189

22. Sarvarova, Y.: Electronic work books: why it is good and what will happen next, ECM-Journal, 2020, [https://ecm-journal.ru/docs/Ehlektronnye-trudovye-knizhki-pochemu-ehto-khorosho-i-chto-budet-dalshe.aspx], accessed on 07/01/2021.

23. Savina, T.N.: Digital economy as a new development paradigm: challenges, opportunities and prospects, Finance and Credit, 24(3.771) 2018, p. 579-590.

- DOI: https://doi.org/10.24891/fc.24.3.579

24. Tereliansky, P.V. et al.: The Concept of Digital Supervision of Compliance with Labor Legislation, in: "Smart Technologies" for Society, State and Economy. ISC 
2020. Lecture Notes in Networks and Systems, vol 155, Springer, Cham, 2021, p. 11-19.

- DOI: https://doi.org/10.1007/978-3-030-59126-7_2

25. The State Duma: Federal Law of December 16, 2019 N 439-FZ “On Amendments to the Labor Code of the Russian Federation in terms of generating information about labor activity in electronic form”, [https://rg.ru/2019/12/19/trud-dok.html], accessed on 07/01/2021.

26. Tomashevsky, K.L.: Digitalization and its impact on the labor market and labor relations (theoretical and comparative legal aspects), Bulletin of St. Petersburg University. Right, 11(2) 2020, p. 398-413.

- DOI: https://doi.org/10.21638/spbu14.2020.210

27. UNCTAD: UNCTAD “Digital Economy Report 2019”, [https:/unctad.org/system/files/official-document/der2019_en.pdf], accessed on 07/01/2021.

28. Waas, B. et al.: Digital economy and the law: introduction to this Special Issue, Work Organisation, Labour and Globalisation, 12(2) 2018, p. 7-11.

- DOI: https://doi.org/10.13169/workorgalaboglob.12.2.0007 